\title{
Synchronized Agricultural Credit and Diversification Adoption to Catastrophic Risk Manage for Wheat Production in Punjab, Pakistan
}

\section{Dilshad Ahmad ( $\sim$ dilshad@ciitvehari.edu.pk)}

COMSATS University Islamabad, Vehari Campus Pakistan https://orcid.org/0000-0002-3991-805X

\section{Muhammad Afzal}

Preston University Islamabad, Pakistan

\section{Research Article}

Keywords: Agricultural credit, Catastrophic risk, Diversification, Probit model, Pakistan

Posted Date: November 9th, 2021

DOl: https://doi.org/10.21203/rs.3.rs-921430/v1

License: (c) (i) This work is licensed under a Creative Commons Attribution 4.0 International License.

Read Full License

Version of Record: A version of this preprint was published at Environmental Science and Pollution Research on April 23rd, 2022. See the published version at https://doi.org/10.1007/s11356-022-20336-5. 
for wheat production in Punjab, Pakistan

3

Corresponding author: dilshad@ ciitvehari.edu.pk https://orcid.org/0000-0002-3991-805X

\author{
Muhammad Afzal \\ Department of Economics \\ Preston University Islamabad, Pakistan \\ profafzal@gmail.com
}




\section{Abstract}

54 Catastrophic risks caused severe affects on agricultural production particularly in developing countries due to consecutive occurrence of unfavorable climate events. Farmers adopt risk management strategies to minimize marketing, production and financial risks in agriculture. The purpose of this study is to investigate the potential association and implementing synchronized agricultural credit and diversification adoption to catastrophic risk manage for wheat production in Punjab, Pakistan. This study used stratified random sampling technique for collecting data of 480 wheat farmers' respondents from production based categorized six districts of Punjab Pakistan. Multinomial and bivariate probit regression models were used in the study to examine the effects of farm and social feathers, disastrous risks farmers view and their attitude to sources of risk moreover potential relationship in agricultural credit and diversification as risk management strategy. Estimates of the study indicated the association in risk management strategies adoption while adopting single risk management strategy motivates farmers to adopt another strategy at same time. Furthermore, findings also indicated as farmer schooling, age, family return, ownership of land, farm size and farmer risk oppose character were highlighted the most influenced features for adopting various risk management strategies. Policy makers and state based authorities can be assisted by the accumulated information of multinomial and bivariate probit regression models in evaluating plans of risk management and willingness of farmer in accept government supported risk managing strategies in incidence of traditional practices for managing farmhouse risk.

Keywords; Agricultural credit, Catastrophic risk, Diversification, Probit model, Pakistan

\section{Introduction}

In global scenario, storms, cyclones, floods and drought are considered some major and frequent natural hazards in the current couple of decades owing to increased incidence of severe climate change (Teo et al., 2018; Carter, 2019; Ahmad and Afzal, 2021). These natural hazards generally

82 Kreft et al., 2016; IPCC, 2019; Ahmad et al., 2019) whereas having no economic, social,

83 political, geographical and cultural boundaries of continents, countries and communities (Daniell 
et al., 2016; IPCC, 2018; Ahmad et al., 2021). Increasing frequency and severity of these natural

85 hazards caused globally severe economic cost and human losses (Gorst et al., 2015; Abbas et al., 2017; Muricho et al., 2019). In current era, owing to increasing vulnerability of climate change, mounting tendency of sever of natural disasters was estimated with disastrous fatalities (IPCC, 2019; Ahmad and Afzal, 2021) such scenario predicted as natural calamities regarding human fatalities expected to twice till 2050 (Doocy et al., 2013; Wilkinson and Brenes, 2014). Floods among natural hazards are estimated recurrently and foremost reason of dead regarding human and commonly basis social and economic risks (Stocker, 2014; Daniell et al., 2016). In global climate index scenario, Pakistan ranked $5^{\text {th }}$ most climate change affected country of the world and expected to rise in temperature 2 to $3 \%$ and variations in rainfall till 2050 (Kreft et al., 2016;

94 Eckstein et al., 2021). In couple of decades, the reason of climatic variations Pakistan frequently faced extreme events of floods which consequently worsen rural living due to reduced significant crops productivity (Abid et al., 2016; Ahmad and Afzal, 2021). Agriculture employs 43.5\% labor force of the country where $64 \%$ population of country inhabited in rural areas (PBS, 2020) so there is significant role of agriculture in subsistence living of rural population where agricultural resilience from climate vulnerability most important for economic stability of the country. In Pakistan, cereal crops more specifically the wheat crop severely affected by climate change (Ahmad and Afzal, 2020) which raised the issue of food security for population of the country 103 (GOP, 2020). In cereal crops, wheat is one of the major food crop which is major sources of 104 staple diet for population and Pakistan is $8^{\text {th }}$ major wheat producer of the world (FAO, 2020). In agriculture, wheat crop contributes $9.2 \%$ in agricultural value added and share $1.8 \%$ in GDP of the country (PBS, 2021). In 2020, Pakistan produced 25.248 million tonnes wheat with estimated yield of 2,867 (Kgs/Hectares) which is relatively lower rather than other countries of the world (PBS, 2021). Punjab province produces major share as $77 \%$ of total wheat production of the country (PBS, 2020). In the couple of decades, consecutive occurrence of catastrophic threats

110 such as floods, drought and storms severely affected the major crops more particularly the 111 cereals crops (Kresft et al., 2016; Kukal and Irmak, 2018; Ahmad and Afzal, 2020), the reason of 112 consecutive hail, storms, erratic rains and floods in harvesting season while drought in growing 113 season (Gorst et al., 2015; Ahmad et al., 2019). In this scenario, for minimizing the severe 114 impacts these natural hazards due to climate change there is appropriate need of significant 115 measures for developing risk management policies. 
117 In developing countries, farmers more particularly use two types of risk management strategies 118 as risk managing strategies and risk lessening strategies (Ahmad and Afzal, 2020, Adnan et al., 119 2021) which further more specifically categorized as informal and formal strategies (Akhtar et 120 al., 2019; Ahmad et al., 2019). Strategy applied at farm level known as informal strategy whereas 121 input subsidization, policies of crop insurance, pricing policy, microcredit and other government 122 and institutional based policies are indicated as formal strategies (Daniell et al., 2016; Muricho et 123 al., 2019). In Pakistan, agricultural credit, off-farm and on-farm diversification more preferred 124 practices as applied by farmers regarding risk management strategies (Ahmad and Afzal, 2021). 125 Redistributive of productive assets of farm estates which mostly consist of resources, other 126 grower shares, equipments and farm land properly known as on-farm diversification (Adnan et 127 al., 2019). Alleviating the risks and differences regarding farmer income using the practices of 128 diversification is more significant aspect as mostly practiced in farming community (Ahmad and 129 Afzal, 2020). Farming risk can more significantly reduced by diversifying agricultural 130 enterprises and productive activities of agriculture (Lu et al., 2017; Arora et al., 2019) such as 131 simultaneously producing various crops and specifying agricultural land for other crops or goods 132 (Akhtar et al., 2019; Adnan et al., 2019). To overcoming other financial risks or other related 133 income variations all such are closely associated with adaptation of off-farm income 134 diversification. Minimizing risks effects and boosting up family income, family members instead 135 of off-farm practices take part in farming activities (Teo et al., 2018; Alam et al., 2020). 136 Agricultural credit particularly used for monetary needs to purchasing agricultural inputs such as 137 machinery, soil cultivation, seeds and fertilizer as well as for using risk management adaptation 138 (Ahmad et al., 2019; Adnan et al., 2020).

140 In literature, during the last couple of decades catastrophic risk management issue more 141 specifically discussed where some significant studies addressed significant effect of 142 socioeconomic factor on adoption catastrophic risk management strategies such as schooling 143 level (Grace et al., 2015; Harrison et al., 2017; Ahmad et al., 2019; Adnan et al., 2020), 144 respondent age (Ayal et al., 2018; Rehman et al., 2020; Ahmad and Afzal., 2021), size of family 145 (Opiyo et al., 2015; Wako et al., 2017; Harrison et al., 2017; Akhtar et al., 2019), experience of 146 farming (Kagunyu et al., 2016; Mekuyie et al., 2018; Adnan et al., 2020), size of land 147 (Holdschlag and Ratter, 2016; Akhtar et al., 2019; Ahmad et al., 2021), income (Dong et al., 
2016; Mekuyie et al., 2018; Rizwan et al., 2020; Ahmad and Afzal, 2020), ratio of land 149 ownership (Thornton and Geber, 2010; Zulfiqar et al., 2016; Arjjumend, 2018), risk attitude and risk perception (Hurst et al., 2012; Debela et al., 2015; Ambelu et al., 2017; Fanta et al., 2019; Ahmad et al., 2019; Saqib et al., 2021; Ahmad and Afzal, 2021). Some studies focused the aspect

152 of catastrophic risk assessment (Seo and Mendelsohn, 2008; Schlenker and Lobell, 2010; Dadzie and Acquah, 2012; Ayal et al., 2018; Nori et al., 2019), catastrophic risk mitigation (Bradshaw et al., 2004; Seager et al., 2006; Metz et al., 2007; Saqib et al., 2018; Muricho et al., 2019) and adaptation of catastrophic risk management strategies (Bryan et al., 2009; Alam et al., 2012; Grace et al., 2015; Opiyo et al., 2015; Mugi-Ngenga et al., 2016; Harrison et al., 2018; Kgosikoma et al., 2018; Ahmad and Afzal, 2020)

There is limited research scenario regarding catastrophic risk management strategies in the aspect of farm diversification in which some studies discussed off-farm diversification as risk management tool (McNamara and Weiss, 2005; Thornton et al., 2007; Kabubo-Mariara, 2008; Ahmed, 2012; Ullah and Shivakoti, 2014), some studies focused the off-farm diversification as mitigation tool (Adnan et al., 2019; Ahmad and Afzal, 2020). Limited studies elaborated the aspect of farm credit as catastrophic risk managing tool (Fayaz et al., 2006) and combined diversification and farm credit aspect as catastrophic risk managing strategy (Adnan et al., 2021). Farmer's behavior regarding the frequent adaptation measures with associated agricultural credit and farm diversification is most probably unidentified to boot. More specifically in developing countries particularly in Pakistan such type of research aspect not properly addressed according to best knowledge of authors. In finding out this research gap, objective of this study is to investigate synchronized agricultural credit and diversification adoption to catastrophic risk manage for wheat production in Punjab, Pakistan. This study is classified in to five sections as

172 introduction of the study explained in first section and material and method elaborated in section.

173 Results indicated in third section whereas discussion illustrated in fourth section. Last section of 174 the study highlighted the conclusion and suggestions section of the study.

\section{Material and method}

177 2.1. Study area

178 In four provinces of Pakistan, Punjab sharing almost 26\% area and 53\% population of the 179 country also represents major fertile lands of the country (PBS, 2020). On the basis of some 
180 considerable reasons Punjab mainly chosen for this study firstly, Punjab contributes major 53\% 181 agricultural GDP shares of the country (PBS, 2020), secondly Punjab produces almost $77 \%$ total 182 wheat production of the country (PBS, 2019). Thirdly in the couple of decades due to climate 183 change and extreme environmental variations, cereal crops more specifically rice and wheat were 184 severely affected by consecutive occurrence of stormy rains, hail and drought particularly in 185 harvesting and growing season of crops. Lastly, in recent decade this country faced five repeated 186 floods since 2010 to 2015 and as compared to other provinces Punjab was more rigorously 187 affected by these floods with heavy losses of crops, livestock, human lives and destruction of 188 infrastructure (NDMA, 2018; PDMA, 2019).

[Figure 1]

190 In such state of affairs of above reasonable substantial factors, Punjab province particularly 191 selected for this study and based on wheat production six districts were specifically categorized 192 and purposively preferred (BOS, Punjab, 2018). In the scenario of study area selection, Dera 193 Ghazi Khan and Layyah from low wheat producing districts, Muzaffargarh and Vehari from 194 medium wheat producing districts and Rahim Yar Khan and Bahawalnagar from high wheat 195 production districts were chosen (PBS, 2019) as illustrated in figure 2 as given below. 196 Divergence standing in these six districts was estimated about socioeconomic structure, 197 geographical variation and climate change and risk experience. In the couple of decades, higher 198 environmental variation and unexpected climate change was estimated such as discrete pattern of 199 monsoon rainfall season and dynamics of average temperature which caused frequent and sever 200 natural hazards (Abid et al., 2015; Ahmad and Afzal, 2020). Environmental scenario of province 201 is hot in summer and cold in winter, Abid et al (2015) with disperse pattern as 70\% rainfall from 202 June to September (Ahmad and Afzal, 2021).

[Figure 2]

204 2.2. Sampling framework

205 In procedure of wheat farmer's data collection and study area selection this study employed the 206 multistage stratified random sampling approach. In the first stage, the reason of significant 207 contribution (77\%) in wheat production of country (BOS, 2018), Punjab province was 208 purposively selected, whereas based on categorized low, medium and high wheat production 209 areas in province, six districts were randomly selected in the second stage. In the third stage, 210 applying the stratified random sampling approach union councils from each districts were chosen 211 whereas in fourth stage by using the accurate record of revenue department, villages from each 
212 union council were selected. In the last stage, for interviewing procedure framework eighty

213 wheat farmers from each district were randomly selected and total 480 wheat farmers' data was

214 collected from these six districts as illustrated in the table 1.

[Table 1]

216 For accessing the appropriate information of wheat farmers related to their farm experience, age,

217 schooling, farm size, family size, income, credit, diversification adoption, farmers risk

218 perception and attitude to wheat crop, hailstorm, heavy wind, drought, diseases and pests, heavy

219 rains and floods, this research work used the well-structural questionnaire. Enumerator the

220 students of COMSATS University Vehari firstly trained for collection of data from the study

221 area and for capturing missing information regarding data collection, questionnaire was pre-

222 tested. In the study area data was collected from July to September in 2019 while former to data

223 collection wheat farmers of the study area were well-informed regarding aim and application of

224 data. Mostly farmers from the study area warmly participated in sharing their information

225 regarding wheat crop whereas 34 farmers refused to participate as they replaced to other farmers

226 as data collection procedure illustrated in figure 3.

[Figure 3]

$228 \quad 2.2$ Empirical specification

229 In numerous risk management preferences, agricultural credit and diversifications are some 230 significant preferences particularly used like dependent variable for this study. Farmers have to 231 select strategy base preferences out of four combinations in this multinomial probit model, (i) 232 neither adopting any risk management strategy (neither agricultural credit nor diversification),

233 (ii) adopting only diversification (off-farm or on-farm), (iii) adopting only agricultural credit 234 strategy (iv) adopting both strategies (diversification and agricultural credit). Farmers risk 235 management adopting preferences proportion illustrated in table 2 which highlights as in overall 236 sample farmers of the study area, $18.87 \%$ farmers adopted diversification strategy, $23.97 \%$ 237 farmers used agricultural credit strategy, $21.63 \%$ farmers adopted both risk management 238 strategies whereas $35.53 \%$ farmers adopted no risk management strategy.

240 Description of variables

241 Dependent variables

242 Agriculture credit and adoption of diversification considered dependent variables in this research 243 work. Institutions (banks) provide any credit or loan for agriculture purpose particularly 
244 recognized as agricultural credit (Ahmad et al., 2019). Such types of financial credit facilitate 245 farmers' to buy farming inputs for smoothly running the farming operations. Losses and gains in 246 farming practices are materialized by the completion of production and selling process of 247 agricultural outputs. Consequently, for appropriate application of risk strategy in agriculture, 248 credit access play significant role as this agriculture credit access includes as dependent dummy 249 variable as indicating 0 for not using agriculture credit and 1 for highlighting using agricultural 250 credit in farming practices. Diversification is considered as tactics for increasing off-farm and 251 on-farm income sources by farming community from the dawn of agriculture (Rehan et al., 252 2017). Farming community for mitigating severe financial affects of climate change and 253 enhancing their household income specifically uses diversification whereas inter-cropping and 254 crop diversification are among few types of on-farm diversification (Akhtar et al., 2019; Ahmad 255 and Afzal, 2020). In this research work diversification indicated as dummy variable illustrating 0

256 as farmer not using diversification whereas 1 for farmers using diversification in their farming 257 practices.

259 Independent variable

260 In literature, farmers education, age, family income, farming experience, farm proprietorship and 261 farm area consider significant factors for influencing and assessing farmers risk attitude toward 262 climate change (Akhtar et al., 2019; Adnan et al., 2020; Ahmad and Afzal., 2020).

264 2.3. Assessing risk perception

265 Risk perception more properly illustrate by Wang and Roush, (2000), as imminent state of affairs 266 in screening the mode of a bit going away incorrect and its forthcoming cost. Likelihood 267 outcomes and its forthcoming product properly level risk detailed the same as a risk factor 268 (Cooper et al., 2005). Risk of hailstorm, risk of heavy wind, risk of drought, risk of diseases and 269 pests, risk of heavy rains and flood risk were categorized as high-flying risks in this study. In the 270 scenario of farm potential in sequence of measuring incidence and severity regarding risk of 271 farmer this study used Liker Scale which varies from 1 to 10. Several important studies 272 Senkondo, (2000), Fahad et al., (2018), Ogurtsov et al., (2008), Akhtar et al., (2018) and Adnan 273 et al., (2021) used this approach for risk perception in which respondents were reported to risk 274 matrix, these scores were ranged accordingly higher risk severity 6 to 10 and lower risk severity 
2751 to 5 (Cooper et al., 2021) as indicated in figure 4. In estimation procedure, risk perceptions

276 were used like in view of no risk specified as 0 whereas for high risks pointed out as 1.

278 2.4. Assessing risk attitude

279 In literature risk attitude measured through various approaches where two most appropriate 280 approaches frequently applied for risk attitude measurement properly renowned as direct and 281 indirect approaches (Dadzie and Acquah, 2012). Direct method generally known as interview 282 process related to favorites of farmer's elicitation more used to name of Neumann and 283 Morgenstern (Anderson et al 1977). Several significant studies in literature Torkamani, (2005), 284 Iqbal et al., (2016), Smidts et al., (1990), Hardaker et al., (2010), Ahmad et al., (2019), Ogurtsov 285 et al., (2008), Ahmad and Afzal (2020), Rizwan et al., (2020), Saqib et al., (2018) and Adnan et 286 al., (2021) applied Equally Likely Certainty Equivalent Method (ELCEM) by diverse methods 287 which is properly identified adapted version of Neumann-Morgenstern (N-M) model. In the 288 proxy of economic scenario Elicit Utility model is frequently used to ELCEM while Certainty 289 Equivalents (CE) is subdivision of sequence the risky outcomes in contrasting values of utility 290 (Binici et al., 2003). In relevant to series work of Binici et al., (2003) utility function employed 291 this research works denoted as wealth symbol as perception income of household. There is close 292 and direct relationship illustrated regarding monetary proportion and risk, higher risk as higher 293 monetary value. In such state of affairs, respondent were provoked to show the value of specific 294 outcome to make possible prepared them indifferent in choose connecting risky outcomes by 295 particular of overall income of household in monetary term changeable as 300000 (PKR) to 0 296 with related possibility of as 0.5 in loss and income scenario. In such scenario, farmers were 297 assured outcome of income 200000 (PKR) it carry on to be indifferent. The outcome chain was 298 particular wedged in 0 to 200000(PKR) as leftover of respondent be indifferent $100000(\mathrm{PKR})$. In 299 further procedure farmer by wish sequence connecting of 100,000(PKR) states similar assure via 3000 and indicate the indifferent with 50000(PKR). In advance procedure sum as $40000(\mathrm{PKR})$ in 301 indifferent classification of farmer, as such assessment was continual. In higher chain of 302 200000(PKR) to 300000(PKR), farmers have to make a decision and continue indifferent in 303 180000(PKR). In more sequence of 180000(PKR) to 300000(PKR), farmers stay indifferent in 304 220000(PKR). In such situation of reappearance of examination through association of 305 likelihood, some number CE spots were consequential. In such scenario, value of utility used of $30650,000(\mathrm{PKR})$ estimated as 


$$
U(50,000)=0.5 u(0)+0.5 u(100,000)=0.5(0)+0.5(1)=0.5
$$

308 In situation for more managing diverse CE, furthermore matching them with utility values, cubic 309 utility function was applied for estimation utility for each entity respondents. Cubic utility 310 function highlighted in given equation 2.

$$
U(\text { wealth })=\alpha_{1}+\alpha_{2} \text { wealth }+\alpha_{3} \text { wealth }^{2}+\alpha_{4} \text { wealth }^{3}
$$

312 Risk attitude of farmers based on many factors whereas wealth of farmer illustrated as w even as

$313 a$ detailed parameters as specified in equation 2. Cubic Utility Function has close association by 314 risk indifferent attitude, aversion risk and preferring risk, (Binic et al., 2003).

Utility frequently evaluated by method of ordinary scale whereas form of utility function regarding ordinary scale be capable to transformed risk aversion in level of quantitative nature know as absolute risk aversion (Pratt, 1964; Raskin and Cochran, 1986; Arrow, 2000). Arithmetic appearance of absolute risk aversion can be specified as

$$
r_{\alpha}(\text { Wealth })=-\frac{U^{\prime}(\text { Wealth })}{U^{\prime}(\text { Wealth })}
$$

321 Absolute risk aversion illustrated as $r_{\alpha}(W)$ in equation (3) whereas derivatives of second order 322 and first order of wealth (w) indicated as $U^{\prime}$ and $U^{\prime}$ '. In such situation respondent income status 323 reported as their wealth (Olarinde et al., 2007). Coefficient sign illustrated the respondent risk 324 behavior; respondents risk likely behavior indicated as negative sign, respondents indifferent risk 325 behavior shows zero value coefficient whereas coefficient of positive sign highlights the 326 respondents absolute risk aversion. Range of 0 or 1 shows respondents risk attitude whereas no risk aversion attitude of respondent is explained as 0 while risk aversion attitude as 1.

\section{Model specification}

330 In analyzing the farmer's agricultural credit and adaptation decisions on diversification this study 331 used both multinomial and bivariate probit models. Bivariate probit model is employed for 332 likelihood of simultaneous association of different decisions for put in to practice diverse risk 333 management policies (Ullah et al., 2015; Ahmad and Afzal, 2020; Adnan et al., 2021) whereas 334 for contrasting the estimates individual probit model was employed. Bivariate probit model 335 equation as illustrated

$$
Y_{i j}=X_{i j} \beta_{i j}+\varepsilon_{i j}
$$


337 In above equation, agricultural credit or diversification as adopted risk management strategies 338 indicated as $\mathrm{Y}_{\mathrm{ij}}$ with ith respondents $(\mathrm{i}=1,2,3 \ldots \ldots)$. Observed variables vectors that posses the 339 influences on adoption procedure of risk management strategies indicated as $\mathrm{X}_{\mathrm{ij}}$ whereas the

340 evaluated vectors of unknown parameters indicated as $\beta_{\mathrm{ij}}$ and error term of unobserved shown as $341 \varepsilon_{\mathrm{ij}}$. In this equation $\mathrm{Y}_{\mathrm{j}}$ indicated as binary variable that illustrated the $\mathrm{m}$ equation format as 342 indicated in the below equations

$$
\begin{gathered}
\mathrm{Y}_{11}{ }^{*}=\alpha_{11}+\mathrm{X} \beta_{11}+\varepsilon_{11} \\
\mathrm{Y}_{21}{ }^{*}=\alpha_{21}+\mathrm{X} \beta_{21}+\varepsilon_{21}
\end{gathered}
$$

345 In the above equation 5 and 6 latent variables are denoted by the notion of $\mathrm{Y}_{11}{ }^{*}$ and $\mathrm{Y}_{21}{ }^{*}$ which

346 highlighting to emphasizing any decisions regarding risk managing approach. Multinomial probit 347 regression used the set of probable arrangements rather than alternative risky decisions (Adnan et 348 al., 2020). In this research work the two risk management strategies indicated probable 349 combination whereas the multinomial probit regression illustrated as in equation 7.

$$
Y_{i j}=X_{i j} \beta+\varepsilon_{i j}
$$

351 In equation $7, \mathrm{Y}_{\mathrm{i}}$ shows the several combination of risk management choices reported as $\left(\mathrm{Y}_{\mathrm{i}}=\right.$ $3521,2,3,4 \ldots . \mathrm{m})$ as $\mathrm{ith}$ choices $(\mathrm{ij}=1,2,3, \ldots \ldots \mathrm{n})$ from the respondents whereas $\mathrm{X}_{\mathrm{ij}}$ highlights the 353 vectors (1xk) that shows the observed variables which impacts on the making choice. In this 354 equation unknown parameters are illustrated by $\beta$ and unobserved random error denoted as $\varepsilon_{\mathrm{ij}}$. In 355 such scenario $\varepsilon_{\mathrm{ij}}$ highlighted is presumptuous as the multivariate standard with variance 356 covariance and with zero mean.

\section{Results}

359 Research work variables descriptive statistics has elaborated in table 2. Respondent farmers 360 illustrated higher perception of floods, heavy rains, pests and diseases major risk factors in the 361 study districts to wheat crop production rather than drought and hail storm. Farmers in the study 362 area adopted some significant adaptation strategies to stooping costs from various environmental 363 risks. In the study area, $47 \%$ farmers used off-farm or on-farm diversification adaptation strategy 364 for risk management whereas majority of farmers as 53\% used various form of credit to wheat 365 production. Majority of farmer $77 \%$ were found to be risk averse in the study area. Agricultural 366 credit usage $27.5 \%$ indicated as significant adaptation measure for risk management as compared 367 to diversification $22.7 \%$ whereas almost one third $29.59 \%$ farmers have adopted no risk 368 management strategy in the study area. 
370 Bivariate probit and individual probit models estimates are indicated in table 3 , which 371 determined the correlation coefficient of agricultural credit and diversification for purpose of risk 372 managing technique by using the probit estimations. In Bivariate probit and individual probit 373 models, positive correlation coefficient regarding both risk control methods as verified the 374 estimated by sustaining null hypothesis indicating as risk management decision error term is 375 correlated. Regarding these estimates instead of using the regression probit of two independent it 376 is more suitable to involve bivariate probit model. Positive correlation coefficient illustrates the 377 indication as selection of one risk management strategy significantly influences the other 378 strategy. Wald $\chi^{2}$ test (154.98) and test of log likelihood $\mathrm{p}_{\mathrm{kj}}$ (3.8971) more preferably specifies 379 the bivariate probit regression usage and confirms rejection of hypothesis $\mathrm{H}_{0}$ with conjoint 380 nullity of $\mathrm{p}_{\mathrm{kj}}$.

[Table 3]

382 In risk management decisions for selecting agricultural credit as risk management tool in wheat 383 farming, socioeconomic factors play significant role. In coming to a decision the adaption of 384 agricultural credit to reducing unfavorable catastrophic risks in wheat production of Pakistan 385 farmers schooling, age, family income, farm practices, farm land ownership status, farm size and farmers risk averse nature are considered as most essential factors as showed in table 3. Farmer 387 schooling and size of farm indicated positive correlation with using agricultural credit as 388 adoption of risk management tool. These estimates illustrated as farmers with higher schooling more preferably to using agricultural credit as risk management tool rather than illiterate farmers whereas large farm size farmers more willing to use agricultural credit as risk management tool rather than small farm size farmers. Negative and significant correlation was estimated regarding 392 farmers age and farmer monthly income with using of agricultural credit as risk management 393 tool. Elderly farmers less willing to using agricultural credit as risk management tool rather than 394 young farmers because young farmer more conscious about farming risks. Farmers having 395 increasing monthly income not willing to taking agricultural credit for using as risk management tool whereas farmer with less monthly income more willing to using agricultural credit for risk 397 managing measure. Estimates of the study indicated the negative correlation of farming 398 experience and farmland ownership with using agricultural credit for risk management tool. 399 Estimates illustrated as experienced farmers less willing to using agricultural credit as risk 400 management tool whereas inexperienced more willing to using it as tool of risk management. In 
401 this study area, tenants farmers have higher probability of taking and using agricultural credit for risk management whereas farmers having their ownership of farmland no motivation to using this management measure.

Farmers perceptions regarding the risks of heavy rain, drought, pest and diseases highlighted the favourable affect regarding the adaption of agricultural credit for minimizing the adverse castrophic risks on crops whereas negative perception on agricultural credit was estimated regarding risks of flood, hailstorm and heavy wind. Majority of farmers in the study area having risk averse attitude and such nature of farmers significantly influences in agricultural credit adaption. On the other hand risk perception decisions of farmers have slanted nature and possible the effect to further factors in the process of decision making.

413 In scenario of risk management decisions for choosing diversification in wheat farming, 414 socioeconomic factors such as farmers schooling, age, family income, farm practices, farm land 415 ownership status, farm size and farmers risk averse nature play significant role as illustrated in 416 table 3. Estimates illustrated the positive and significant correlation in respondent's ages and 417 schooling with adaption of diversification strategy. These estimates show as aged farmers rather 418 than young farmers and literate farmers rather than illiterate farmers more willing to adopting 419 diversification as risk management strategy. In such scenario increasing schooling and age raises 420 the probability of more prepared to adopting diversification. Positive and significant coefficient 421 correlation of family monthly income and diversification in estimates elaborated increasing 422 family income raises probability of farmers to adaption diversification. Estimates illustrated the 423 negative relation of farming experience and farmers family size with adoption of diversification 424 strategy. These results indicated when farmers experienced increases and their farm size 425 increases they mostly evade to adoption diversification rather than less experienced farmers and 426 small farm size farmers. Small farm size farmers and less farming experience farmers more 427 likely to adopting diversification. Positive and significant coefficient correlation of ownership 428 farmland with diversification adaption illustrates as compared to tenant farmers land owner more 429 inclined to adoption of diversification so there is favourable effect of farm land ownership on 430 adoption of diversification regarding climate risks.

431 Heavy rains, floods, drought, hail storm, heavy wind, pest and diseases are six significant 432 independent variables of risk perception. Farmers risk perception regarding heavy rain, drought, 
433 pest and diseases showed the positive correlation. These estimated highlighted as farmers have 434 higher risk perception about heavy rains, drought, pest and diseases and more willing to adopting 435 diversification as risk management tool rather than those farmers who have lower risk perception 436 regarding these risks. Farmers risk perception about flood, hailstorm and heavy wind showed the 437 negative correlation indicating as farmers have lower risk perception regarding these risks so less 438 willing to using diversification as risk management strategy rather than those farmers having 439 higher risk perception regarding these risks. Estimates of risk attitude category showed positive 440 correlation illustrating as majority of farmers in study area have risk averse attitude as seeking 441 more risk and eager to using diversification.

442 Agricultural credit and diversification are two more significant risk managing strategies 443 measured in this study which includes four various risk management strategies adoption of 444 agricultural strategy, adoption of diversification, both strategies simultaneous adoption and not 445 adopting any risk management strategy. In estimation of multinominal probit various 446 combinations as illustrated in table 3 indicated as dependent variable (Yi=1...4). Estimates of 447 multinominal probit regression model reported in table 4 where in estimation procedure basic 448 choice is taken the combined no adoption of risk management strategy. Diversification 449 adaptation significantly influenced by farmer schooling, age, monthly income, land area, 450 farmland ownership, farm area, risk perception about to drought, heavy rain, diseases and pest 451 and risk aversion farmer nature. Major findings of factors are alike with previous results rather 452 than farm size and year of farming experience, because these factors negative impact on 453 individual and bivariate probit estimation, whereas multinominal probit model was positively 454 impacted.

456 Adoption of agricultural credit decisions are significantly influenced factors of farmer's monthly 457 income, farmers schooling, ownership of farmland status risk perception about drought, heavy 458 rains, disease and pests. Farmer's tendency regarding risk averse attitude motivates farmers in 459 adoption of agricultural credit for risk management. Major findings are alike individual and 460 bivariate probit regression estimates except ownership of farmland and size of family. 461 Robustness in estimates has indicated the reason of major significant variables both of 462 diversification and agricultural credit in bivariate model showed similar effects like 463 multinominal. In combination 4, farmers adaptation decisions are significantly influenced by 464 factors of farm area, monthly income of farmer, ownership of land risk perception about heavy 
465 rain, drought and pest and diseases also with risk farmers risk aversion status. In the same way, 466 experience of farming and farmers schooling have positive while insignificant on farmers 467 decisions building procedure about agricultural credit adoption for risk managing. Particularly in 468 this research evaluating identification of casual is difficult. Diversification impact related to level of saving is unsure which might have influence agricultural credit adoption for managing 470 castrophic risk.

\section{Discussion}

473 In socioeconomic factors, positive correlation regarding farmers schooling and adoption of 474 diversification strategy was estimated. According to estimates it is observed as qualified farmers 475 more preferably focus to access advance knowledge regarding on-farm or off-farm or both type 476 of diversification measures for improving stability of farm management and enhancing farming 477 income as these finding are in line with the studies of Iqbal et al., (2016), Ahmad et al., (2019) 478 and Adnan et al., (2020). On the other hand, these findings are in contradiction with the studies of Mesfin et al., (2011), Rehima et al., (2013) and Ullah et al., (2015) illustrated as higher educated farmers less willing to adopting diversification in farm activities. Positive relation in age of farmer and diversification in farm activities indicated in this study illustrating as aged farmers mostly are more experienced and more willing to using farm diversification regarding 483 the severe impacts of castrophic risks. Some studies Abbas et al., (2017), Ahmad and Afzal, 484 (2020) and Adnan et al., (2021) are in line with these findings as indicating positive relation of age and diversification adaption whereas some studies Ali et al., (2019), Abbas et al., (2015) and Shah et al., (2021) illustrated negative impact of age with diversification adaption so mix scenario related to age and farm diversification estimated in literature. Higher probability of diversification regarding higher income was indicated in this study illustrating as higher income motivates farmers for adopting more diversification to generating more income sources. Some 490 studies Ahmad and Afzal, (2020), Alam et al., (2020) Shah et al., (2021) and Adnan et al., (2021) 491 findings are in line with estimate of this study whereas the study of Ullah and Shivakoti (2015) 492 indicated the reverse causality as negatively related of higher income regarding on-farm 493 diversification and positive effect of higher income to off-farm diversification. Farming 494 background of farmers more properly known experienced farmers harmed the adoption of 495 diversification strategy. Experienced farmers are mostly skilful focus higher priority to 496 traditional measures for overcoming catastrophic risks rather than using advance technical skill 
and diversification strategies. These findings are in line with the studies of Abbas et al., (2015)

498 Ali, (2018) and Rahman et al., (2020) indicating as negative correlation of experience of farming 499 and adoption of diversification strategy whereas some studies Ashfaq et al., (2008), Iqbal et al., 500 (2016) and Ahmad et al., (2019) showed positively related of farming experience and 501 diversification adoption. Farm size and adoption of diversification strategy illustrated the 502 negative correlation in the findings of this study indicating as small farm size farmers for 503 overcoming catastrophic risks more prefer to adopt the strategy of diversification whereas large 504 farm size farmers slightly requires to risk management tools due to enlarged capacity of risk 505 bearing. Small farm size farmers the reason of limited resources having minimal capacity of risk 506 bearing causes to focus adopting risk management strategy like diversification rather than large 507 farm size farmers as these findings are in line with the studies of Ahmad and Afzal, (2020), 508 Rizwan et al., (2020) and Adnan et al., (2021). Some studies Kouame, (2010), Saqib et al., 509 (2016) and Ali, (2018) indicated the positive correlation of farm size and diversification, 510 showing as large farm size farmers more need adoption strategies to risk managing measure 511 rather than small farm size farmers. Findings of this research illustrated the positive correlation 512 of farmland ownership with adoption of diversification for overcoming the catastrophic risks 513 management the reason of that owner of farmland as compared to tenants can easily and directly 514 made decisions regarding diversification adaption as risk management decision. These findings 515 are in line with the study of Ashfaq et al., (2008), Iqbal et al., (2016), Ahmad and Afzal, (2020) 516 and Adnan et al., (2021) and in contrast with the study of Velandia et al., (2009) illustrated as 517 farmland owner higher capacity regarding risk management due to access of significant 518 resources rather than tenants so use minimal measures for risk management. In choosing the 519 strategy of diversification adoption, the impact of farmers risk perception about drought, heavy 520 rain, pest and diseases is positive whereas impact of negative risk perception regarding flood, 521 hail storm and heavy wind. Flood risk perception in contrast with studies of Ali et al., (2019), 522 Akhtar et al., (2019) and Ahmad et al., (2020) whereas in consistent with the studies of Ullah et 523 al., (2015) and Adnan et al., (2021). The positive drought perception of farmers regarding to 524 wheat crop indicating as wheat crop in Pakistan is grown in winter season where water 525 availability for wheat crop is low causes more issue of drought while flood scenario is extremely 526 low in winter and more probability of summer season. Diversification strategy is mostly adopted 527 by farmers in avoiding production losses and generating income sources through off-farm 528 activates to minimal the risk losses. Water scarcity and castrophic risk causes to yield losses of 
wheat crop which consequently reduces net returns of wheat cultivation. Hail storm and heavy

530 rain threats deterred farmers for adopting diversification as risk management strategy. In

531 decision making process, risk perception of farmer influence indicated as additional determinant.

532 Risk aversion behavior of farmer affects their decisions of diversification regarding adopting the

533 risk management strategy as study findings indicating as majority of farmers in the study area

534 having risk averse nature. These findings are consistent with the studies of Alam et al., (2019)

535 and Ahmad and Afzal, (2020).

537 In findings of the study, positive correlation in farmers schooling and credit access as risk 538 management strategy illustrates as literate farmers are more familiar regarding advantages of 539 agricultural credit access rather than illiterate farmers. Higher schooling facilitates farmers in 540 proper understanding regarding credit access terms and conditions and appropriately managing 541 all proper documentations. These findings are in line with the studies of Saqib et al., (2018), 542 Ahmad et al., (2019), Rehman et al., (2020) and Adnan et al., (2021). Regarding the estimates of 543 the study indicated the negative correlation of farmer's age and adoption of agricultural credit 544 access as risk management strategy. Aged farmers as compared to young farmers less motivated 545 to access agricultural credit for risk management strategy due to it complicated procedure and 546 inadequate information regarding its usage mostly in developing countries and more specifically 547 in Pakistan. Elderly farmers have to face a number of issues regarding complicated 548 documentation of agricultural credit which causes to discourage access of credit. These findings 549 are in line with the studies of Zulfiqar et al., (2016), Rizwan et al., (2020) and Ahmad and Afzal, 550 (2020). Findings of the study indicated the negative correlation in farmer's higher income and 551 diversification adoption. Higher income farmers due to their own saving particularly invest to 552 on-farm for risk managing issues rather than access to agricultural credit to increasing their 553 financial burden. Results biasness can be as if indicating reverse causality as large farms needs 554 more capital from disasters recovery. Accordingly, large farm required more resources for risk 555 management in contrast to small farms and agricultural credit can be as significant tool to 556 managing these catastrophic risks. These findings are consistent with the studies of Abid, (2017), 557 Alam et al., (2019) and Ahmad et al., (2020). Farm size and agricultural credit indicated the 558 positive correlation illustrating as large farms as compared to small farms more need to 559 additional capital for managing catastrophic farming risks. These findings are consistent with the 560 studies of Ullah et al., (2016), Alam et al., (2019) and Adnan et al., (2021) while in contrast with 
561 the study of Saqib et al., (2016). Adverse affect of farmland ownership and agricultural credit 562 estimated in the estimates of this study illustrating as lower attention of farmland owner to access 563 of credit is due to having more stability and assets with enhanced capacity of risk management. 564 These findings are in line with the study of Ali, (2018), Ahamd and Afzal, (2020) and Rizwan et 565 al., (2020). Risk perception of farmers regarding to heavy rain, hail storm, drought and heavy 566 wind correlated negatively whereas positive concerning to flood, diseases and as pests affects on 567 agricultural credit acceptance to minimize disadvantageous climatic risk in agriculture. 568 Agriculture credit mostly used by farmers by choice for lowering and mitigating the major losses 569 from ex-post shocks, crop failure and crop cultivation. More specifically in Pakistan, farmer's 570 income is significantly influenced by these catastrophic risks which directly affects clothing and 571 food expenditures. In due course, without financial support it is not easy for farmers to restart 572 cultivation and production for next production season. Farmers are extremely discouraged in 573 adoption of agricultural credit in drought, heavy rain, hailstorm and heavy wind as these findings 574 are in line with the studies of Ullah et al., (2016), Abid, (2017), Ahmad et al., (2020) and Adnan

575 et al., (2021). In drought situation, majority of farmers avoid participating in crop cultivation and 576 production so not prefer to use credit for such production process. Heavy rain, hailstorm and

577 heavy wind also have severe affects on crop cultivation and production causes to less prefer the 578 usage agricultural credit. Risk averse nature of farmers more preferably motivates farmers to 579 usage of agricultural credit for adaptation measures to catastrophic risks and majority of the 580 study area farmer showed the risk averse nature as these findings are in line with the studies 581 Saqib et al., (2016), Abbas et al., (2017) and Ahmad and Afzal., (2020).

\section{Conclusion and suggestions}

584 Multiple risk management strategies are mostly adopted by farmers to overcoming the catastrophic risks of agricultural production. This study used the multinomial and bivariate probit regression sought to find out the factors influencing farmer's choices of agricultural credit and 587 diversification strategy for managing risks in Pakistan, moreover the potential relationship in these choices. Results of the study indicated the correlation in farmer's adoption of agricultural credit and diversification strategy to managing risks. Findings of the study concluded as farmers 590 adoption of one risk management strategy motivates them at the same time as to adopting other 591 risk managing strategies. Estimates illustrated the significant relationship in risk tolerance nature 592 and socioeconomic factors of farmers related to their adoption the strategy of risk management. 
593 In this study, six production based categorized wheat growing districts of Punjab Pakistan were

594 preferably focused as these outcomes can be extended to various region of country and 595 particularly the other developing countries regarding to availability of various risk managing 596 strategies. Policy makers and state based authorities can be assisted by the accumulated 597 information of multinomial and bivariate probit regression models in evaluating plans of risk 598 management and willingness of farmer in accept government supported risk managing strategies 599 in incidence of traditional practices for managing farmhouse risk. In the same way this study 600 discussed limited researcher's choices and interviewer's decisions because of study focused only

601 limited area of research such as six districts of Punjab Pakistan. In this research, promising 602 conclusions for selecting the poverty and food safety are further than of this study so future 603 research can find out such significant outcomes.

604

\section{Declarations}

606 Ethical Approval

607 Ethical approval taken from the COMSATS University Vehari campus, ethical approval 608 committee

609 Consent to Participate

610 Not applicable

611 Consent to Publish

612 Not applicable

613 Authors Contribution

614 DA analyzed data, methodology, results and discussion, conclusion and suggestions and

615 manuscript write up whereas both DA and MA finalized and proof read the manuscript and both

616 authors read and approved the final manuscript.

617 Funding

618 This study has no funding from any institution or any donor agency.

619 Competing Interests

620 The authors declare that they have no competing interest.

621 Availability of data and materials 
622 The datasets used and/or analyzed during the current study are available from the corresponding 623 author on reasonable request.

\section{References}

Abbas, A., Amjath-Babu, T. S., Kächele, H., \& Müller, K. (2015). Non-structural flood risk mitigation under developing country conditions: an analysis on the determinants of willingness to pay for flood insurance in rural Pakistan. Natural Hazards, 75(3), 21192135.

Abbas, G., Ahmad, S., Ahmad, A., Nasim, W., Fatima, Z., Hussain, S., ... \& Hoogenboom, G. (2017). Quantification the impacts of climate change and crop management on phenology of maize-based cropping system in Punjab, Pakistan. Agricultural and Forest Meteorology, 247, 42-55.

Abid, M. (2017). Does economic, financial and institutional developments matter for environmental quality? A comparative analysis of EU and MEA countries. Journal of environmental management, 188, 183-194.

Abid, M., Scheffran, J., Schneider, U. A., \& Ashfaq, M. J. E. S. D. (2015). Farmers' perceptions of and adaptation strategies to climate change and their determinants: the case of Punjab province, Pakistan. Earth System Dynamics, 6(1), 225-243.

Abid, M., Schilling, J., Scheffran, J., \& Zulfiqar, F. (2016). Climate change vulnerability, adaptation and risk perceptions at farm level in Punjab, Pakistan. Science of the Total Environment, 547, 447-460.

Adnan, K. M., Ying, L., Ayoub, Z., Sarker, S. A., Menhas, R., Chen, F., \& Yu, M. M. (2020). Risk management strategies to cope catastrophic risks in agriculture: the case of contract farming, diversification and precautionary savings. Agriculture, 10(8), 351.

Adnan, K. M., Ying, L., Sarker, S. A., Hafeez, M., Razzaq, A., \& Raza, M. H. (2019). Adoption of contract farming and precautionary savings to manage the catastrophic risk of maize farming: Evidence from Bangladesh. Sustainability, 11(1), 29.

Adnan, K. M., Ying, L., Sarker, S. A., Yu, M. M., \& Tama, R. A. Z. (2021). Simultaneous adoption of diversification and agricultural credit to manage catastrophic risk for maize production in Bangladesh. Environmental Science and Pollution Research, 1-13. 
653 Adnan, K. M., Ying, L., Sarker, S. A., Yu, M., Eliw, M., Sultanuzzaman, M., \& Huq, M. (2021). Simultaneous adoption of risk management strategies to manage the catastrophic risk of maize farmers in Bangladesh. GeoJournal, 86(4), 1981-1998.

Ahmad, D., \& Afzal, M. (2019). Household vulnerability and resilience in flood hazards from disaster-prone areas of Punjab, Pakistan. Natural Hazards, 99(1), 337-354.

Ahmad, D., \& Afzal, M. (2021). Flood hazards, human displacement and food insecurity in rural riverine areas of Punjab, Pakistan: policy implications. Environmental Science and Pollution Research, 28(8), 10125-10139.

Ahmad, D., \& Afzal, M. (2021). Impact of climate change on pastoralists' resilience and

Ahmad, D., Afzal, M., \& Rauf, A. (2019). Analysis of wheat farmers' risk perceptions and attitudes: evidence from Punjab, Pakistan. Natural Hazards, 95(3), 845-861. sustainable mitigation in Punjab, Pakistan. Environment, Development and Sustainability, $1-21$

Ahmad, D., Afzal, M., \& Rauf, A. (2021). Farmers' adaptation decisions to landslides and flash floods in the mountainous region of Khyber Pakhtunkhwa of Pakistan. Environment, Development and Sustainability, 23(6), 8573-8600.

Ahmad, D., Afzal, M., \& Rauf, A. (2021). Flood hazards adaptation strategies: a gender-based disaggregated analysis of farm-dependent Bait community in Punjab, Pakistan. Environment, Development and Sustainability, 23(1), 865-886.

Ahmed, F. F. (2012). Income diversification determinants among farming households in

Akhtar, S., Li, G. C., Nazir, A., Razzaq, A., Ullah, R., Faisal, M., .. \& Raza, M. H. (2019). Maize production under risk: The simultaneous adoption of off-farm income diversification and agricultural credit to manage risk. Journal of integrative agriculture, 18(2), 460-470.

Akhtar, S., LI, G. C., Ullah, R., Nazir, A., Iqbal, M. A., Raza, M. H., ... \& Faisal, M. (2018). Factors influencing hybrid maize farmers' risk attitudes and their perceptions in Punjab Province, Pakistan. Journal of Integrative Agriculture, 17(6), 1454-1462. 
Alam, M. J., Ahmed, K. S., Nahar, M. K., Akter, S., \& Uddin, M. A. (2020). Effect of different sowing dates on the performance of maize. Journal of Krishi Vigyan, 8(2), 75-81.

Alam, M. M., Siwar, C., bin Toriman, M. E., Molla, R. I., \& Talib, B. (2012). Climate change induced adaptation by paddy farmers in Malaysia. Mitigation and Adaptation Strategies for Global Change, 17(2), 173-186.

Ali, A. (2018). Impact of climate-change risk-coping strategies on livestock productivity and household welfare: Empirical evidence from Pakistan. Heliyon, 4(10), e00797.

Ali, M. F., Ashfaq, M., Hassan, S., \& Ullah, R. (2019). Assessing indigenous knowledge through farmers' perception and adaptation to climate change in Pakistan. Pol J Environ Stud, 29(1), 525-532.

Ambelu, A., Birhanu, Z., Tesfaye, A., Berhanu, N., Muhumuza, C., Kassahun, W., ... \& Woldemichael, K. (2017). Intervention pathways towards improving the resilience of pastoralists: A study from Borana communities, southern Ethiopia. Weather and Climate Extremes, 17, 7-16.

Anderson, J. R., Dillon, J. L., \& Hardaker, B. (1977). Agricultural decision analysis. Monographs: Applied Economics.

Arjjumend, H. (2018). Review of Pastoralists' Resilience and Adaptation to Climate Change: Can Technology Help Pastoralists Mitigate The Risks?. International Journal of Bioresource and Stress Management, 9(1), 118-128.

Arora, S., Du, S., Hu, W., Li, Z., \& Wang, R. (2019, May). Fine-grained analysis of optimization and generalization for overparameterized two-layer neural networks. In International Conference on Machine Learning (pp. 322-332). PMLR.

Arrow, K. J. (2000). A comment on cooper. The World Bank Research Observer, 15(2), 172175.

Ashfaq, M., Hassan, S., Naseer, M. Z., Baig, I. A., \& Asma, J. (2008). Factors affecting farm diversification in rice-wheat. Pakistan Journal of Agricultural Sciences, 45(3), 91-94.

Ayal, D. Y., Radeny, M., Desta, S., \& Gebru, G. (2018). Climate variability, perceptions of pastoralists and their adaptation strategies: Implications for livestock system and diseases in Borana zone. International Journal of Climate Change Strategies and Management.

Binici, T., Koc, A. A., Zulauf, C. R., \& Bayaner, A. (2003). Risk attitudes of farmers in terms of risk aversion: A case study of lower Seyhan plain farmers in Adana province, Turkey. Turkish Journal of Agriculture and Forestry, 27(5), 305-312. 
716 Board of Statistics (BOS) Punjab (2018). Punjab statistics 2018, Statistical Division Punjab Government of Punjab, Lahore, Punjab, Pakistan

Bradshaw, B., Dolan, H., \& Smit, B. (2004). Farm-level adaptation to climatic variability and change: crop diversification in the Canadian prairies. Climatic change, 67(1), 119-141.

Bryan, E., Deressa, T. T., Gbetibouo, G. A., \& Ringler, C. (2009). Adaptation to climate change in Ethiopia and South Africa: options and constraints. Environmental science \& policy, 12(4), 413-426.

Carter, M. R. (2019). The economics of poverty traps. C. B. Barrett, M. R. Carter, \& J. P. Chavas (Eds.). Chicago: University of Chicago Press.

Cooper, D. F., Grey, S., Raymond, G., \& Walker, P. (2021). Project risk management guidelines: Managing risk in large projects and complex procurements. John Wiley \& Sons, Inc..

Dadzie, S. K. N., \& Acquah, H. D. G. (2012). Attitudes toward risk and coping responses: The case of food crop farmers at Agona Duakwa in Agona East District of Ghana.

Daniell, H., Lin, C. S., Yu, M., \& Chang, W. J. (2016). Chloroplast genomes: diversity, evolution, and applications in genetic engineering. Genome biology, 17(1), 1-29.

Daniell, J., Wenzel, F., \& Schaefer, A. (2016, April). The economic costs of natural disasters globally from 1900-2015: historical and normalised floods, storms, earthquakes, volcanoes, bushfires, drought and other disasters. In EGU general assembly conference abstracts (pp. EPSC2016-1899).

Debela, N., Mohammed, C., Bridle, K., Corkrey, R., \& McNeil, D. (2015). Perception of climate change and its impact by smallholders in pastoral/agropastoral systems of Borana, South Ethiopia. SpringerPlus, 4(1), 1-12.

Dong, S., Kassam, K. A. S., Tourrand, J. F., \& Boone, R. B. (2016). Building resilience of human-natural systems of pastoralism in the developing world. Edited by Shikui Dong, Karim-Aly S. Kassam, Jean François Tourrand and Randall B. Boone. Switzerland: Springer.

Doocy, S., Daniels, A., Packer, C., Dick, A., \& Kirsch, T. D. (2013). The human impact of earthquakes: a historical review of events 1980-2009 and systematic literature review. PLoS currents, 5.

Eckstein, D., Künzel, V., \& Schäfer, L. (2021). Global Climate Risk Index 2021. Who Suffers Most from Extreme Weather Events, 2000-2019. 
Fahad, S., \& Wang, J. (2018). Farmers' risk perception, vulnerability, and adaptation to climate change in rural Pakistan. Land use policy, 79, 301-309.

Fanta, V., Šálek, M., \& Sklenicka, P. (2019). How long do floods throughout the millennium remain in the collective memory?. Nature communications, 10(1), 1-9.

FAO, (2020) FAOs Work on Climate Change, United Nations Climate Change Conference 2019, http://www.fao.org/3/ca7126en/ca7126en.pdf

Fayaz, M., Jan, D., Jan, A. U., \& Hussain, B. (2006). Effects of short term credit advanced by ZTBL for enhancement of crop productivity and income of growers. Journal of Agricultural and Biological Science, 1(4), 15-18.

GOP (2020) Economic Survey of Pakistan 2019-20, Pakistan Bureau of Statistics, Ministry of Finance Government of Pakistan. http://www.finance.gov.pk/survey_1920.html

Gorst, C., Kwok, C. S., Aslam, S., Buchan, I., Kontopantelis, E., Myint, P. K., ... \& Mamas, M. A. (2015). Long-term glycemic variability and risk of adverse outcomes: a systematic review and meta-analysis. Diabetes care, 38(12), 2354-2369.

Grace, M. F., Leverty, J. T., Phillips, R. D., \& Shimpi, P. (2015). The value of investing in enterprise risk management. Journal of Risk and Insurance, 82(2), 289-316.

Hardaker, J. B., \& Lien, G. (2010). Probabilities for decision analysis in agriculture and rural resource economics: The need for a paradigm change. Agricultural systems, 103(6), 345350.

Harrison, M. T., Cullen, B. R., \& Armstrong, D. (2017). Management options for dairy farms

IPCC, (2018) Global Warming of $1.5{ }^{\circ} \mathrm{C}$ An IPCC Global Warming Report https://www.ipcc.ch/site/assets/uploads/sites/2/2018/07/SR15_SPM_version_stand 
IPCC, (2019) Global Warming of $1.5{ }^{\circ} \mathrm{C}$ An IPCC Global Warming Report https://www.ipcc.ch/site/assets/uploads/sites/2/2019/06/SR15_Full_Report_High_Res.

Iqbal, M. A., Ping, Q., Abid, M., Kazmi, S. M. M., \& Rizwan, M. (2016). Assessing risk perceptions and attitude among cotton farmers: A case of Punjab province, Pakistan. International Journal of Disaster Risk Reduction, 16, 68-74.

Kagunyu, A., Wandibba, S., \& Wanjohi, J. G. (2016). The use of indigenous climate forecasting methods by the pastoralists of Northern Kenya. Pastoralism, 6(1), 1-6.

Kgosikoma, K. R., Lekota, P. C., \& Kgosikoma, O. E. (2018). Agro-pastoralists' determinants of adaptation to climate change. International Journal of Climate Change Strategies and Management.

Kouamé, E. B. H. (2010). Risk, risk aversion and choice of risk management Strategies by cocoa farmers in western Cote D'ivoire. In CSAE conference.

Kreft, S., Eckstein, D., \& Melchior, I. (2016). Global climate risk index 2017: Who suffers most from extreme weather events? Weather-related loss events in 2015 and 1996 to 2015. Germanwatch Nord-Süd Initiative eV.

Kukal, M. S., \& Irmak, S. (2018). Climate-driven crop yield and yield variability and climate change impacts on the US Great Plains agricultural production. Scientific reports, 8(1), 118.

Lu, W., Latif, A., \& Ullah, R. (2017). Simultaneous adoption of contract farming and off-farm diversification for managing agricultural risks: The case of flue-cured Virginia tobacco in Pakistan. Natural Hazards, 86(3), 1347-1361.

McNamara, K. T., \& Weiss, C. (2005). Farm household income and on-and off-farm diversification. Journal of Agricultural and Applied Economics, 37(1), 37-48.

Mekuyie, M., Jordaan, A., \& Melka, Y. (2018). Understanding resilience of pastoralists to climate change and variability in the Southern Afar Region, Ethiopia. Climate Risk Management, 20, 64-77.

Mesfin, W., Fufa, B., \& Haji, J. (2011). Pattern, trend and determinants of crop diversification: empirical evidence from smallholders in eastern Ethiopia. Journal of Economics and Sustainable Development, 2(8), 78-89. 
812 Metz, B., Davidson, O., Bosch, P., Dave, R., \& Meyer, L. (2007). Climate change 2007: Mitigation of climate change. Cambridge Univ. Press.

814 Mugi-Ngenga, E. W., Mucheru-Muna, M. W., Mugwe, J. N., Ngetich, F. K., Mairura, F. S., \& Mugendi, D. N. (2016). Household's socio-economic factors influencing the level of adaptation to climate variability in the dry zones of Eastern Kenya. Journal of Rural Studies, 43, 49-60.

Muricho, D. N., Otieno, D. J., Oluoch-Kosura, W., \& Jirström, M. (2019). Building pastoralists’ resilience to shocks for sustainable disaster risk mitigation: Lessons from West Pokot County, Kenya. International journal of disaster risk reduction, 34, 429-435.

NDMA, Pakistan (2018) Annual Report 2018, National Disaster Management Authority Pakistan. http://www.ndma.gov.pk/

Nori, M., Murgia, R., Iršič, V., Baldi, M., \& Viel, M. (2019). Lyman $\alpha$ forest and non-linear structure characterization in Fuzzy Dark Matter cosmologies. Monthly Notices of the Royal Astronomical Society, 482(3), 3227-3243.

Ogurtsov, V. A., Van Asseldonk, M. P. A. M., \& Huirne, R. B. M. (2008). Assessing and modelling catastrophic risk perceptions and attitudes in agriculture: a review. NJAS: Wageningen Journal of Life Sciences, 56(1-2), 39-58.

Olarinde, L. O., Manyong, V. M., \& Akintola, J. O. (2007). Attitudes towards risk among maize farmers in the dry savanna zone of Nigeria: some prospective policies for improving food production. African Journal of Agricultural Research, 2(8), 399-408.

Opiyo, F., Wasonga, O., Nyangito, M., Schilling, J., \& Munang, R. (2015). Drought adaptation and coping strategies among the Turkana pastoralists of northern Kenya. International Journal of Disaster Risk Science, 6(3), 295-309.

PBS (2020). Economic Survey of Pakistan 2019-2020 Pakistan Bureau of Statistics, Ministry of Finance Statistical Division, Government of Pakistan

PBS (2021). Economic Survey of Pakistan 2020-2021 Pakistan Bureau of Statistics, Ministry of Finance Statistical Division, Government of Pakistan

PDMA Punjab (2019) Annual Report 2019, Provincial Disaster Management Authority Punjab Pakistan. https://pdma.punjab.gov

Pratt, J. W. (1964). I964]:'Risk Aversion in the Small and in the Large,'. Econometrica, 32, 122136. 
843 Rahman, A., Jianchao, L., Adnan, K. M., Islam, M. D. I., Zhao, M., \& Sarker, S. A. (2020). How indebted farmers perceive and address financial risk in environmentally degraded areas in Bangladesh. Environmental Science and Pollution Research, 27(7), 7439-7452.

Raskin, R., \& Cochran, M. J. (1986). Interpretations and transformations of scale for the PrattArrow absolute risk aversion coefficient: Implications for generalized stochastic dominance. Western Journal of Agricultural Economics, 204-210.

Rehman, A., Jingdong, L., Chandio, A. A., \& Hussain, I. (2017). Livestock production and population census in Pakistan: Determining their relationship with agricultural GDP using econometric analysis. Information Processing in Agriculture, 4(2), 168-177.

Rizwan, M., Ping, Q., Saboor, A., Ahmed, U. I., Zhang, D., Deyi, Z., \& Teng, L. (2020). Measuring rice farmers' risk perceptions and attitude: Evidence from Pakistan. Human and Ecological Risk Assessment: An International Journal, 26(7), 1832-1847.

Saqib, S. E., Arifullah, A., \& Yaseen, M. (2021). Managing farm-centric risks in agricultural production at the flood-prone locations of Khyber Pakhtunkhwa, Pakistan. Natural Hazards, 107(1), 853-871.

Saqib, S. E., Kuwornu, J. K., Panezia, S., \& Ali, U. (2018). Factors determining subsistence farmers' access to agricultural credit in flood-prone areas of Pakistan. Kasetsart Journal of Social Sciences, 39(2), 262-268.

Schlenker, W., \& Lobell, D. B. (2010). Robust negative impacts of climate change on African agriculture. Environmental Research Letters, 5(1), 014010.

Seager, M. (2006). The concept of 'psychological safety'-a psychoanalytically-informed contribution towards 'safe, sound \& supportive'mental health services. Psychoanalytic Psychotherapy, 20(4), 266-280.

Senkondo, E. M. (2000). Risk attitude and risk perception in agroforestry decisions: the case of Babati. Tanzania PhD thesis Wageningen University, Wageningen.

Seo, S. N., \& Mendelsohn, R. (2008). An analysis of crop choice: Adapting to climate change in South American farms. Ecological economics, 67(1), 109-116.

Shah, A. A., Gong, Z., Khan, N. A., Khan, I., Ali, M., \& Naqvi, S. A. A. (2021). Livelihood diversification in managing catastrophic risks: evidence from flood-disaster regions of Khyber Pakhtunkhwa Province of Pakistan. Environmental Science and Pollution Research, 1-14. 
874 Smidts, A. (1990). Decision making under risk: a study of models and measurement procedures with special reference to the farmer's marketing behavior. Agricultural University.

Stocker, T. (Ed.). (2014). Climate change 2013: the physical science basis: Working Group I contribution to the Fifth assessment report of the Intergovernmental Panel on Climate Change. Cambridge university press.

Thornton, P. K., \& Gerber, P. J. (2010). Climate change and the growth of the livestock sector in developing countries. Mitigation and adaptation strategies for global change, 15(2), 169184.

Wako, G., Tadesse, M., \& Angassa, A. (2017). Camel management as an adaptive strategy to climate change by pastoralists in southern Ethiopia. Ecological Processes, 6(1), 1-12.

Thornton, P. K., Herrero, M. T., Freeman, H. A., Okeyo Mwai, A., Rege, J. E. O., Jones, P. G., \& McDermott, J. J. (2007). Vulnerability, climate change and livestock-opportunities and challenges for the poor. Journal of Semi-Arid Tropical Agricultural Research.

Torkamani, J. (2005). Using a whole-farm modelling approach to assess prospective technologies under uncertainty. Agricultural systems, 85(2), 138-154.

Ullah, R., \& Shivakoti, G. P. (2014). Adoption of on-farm and off-farm diversification to manage agricultural risks: Are these decisions correlated?. Outlook on Agriculture, 43(4), 265-271.

Ullah, R., Jourdain, D., Shivakoti, G. P., \& Dhakal, S. (2015). Managing catastrophic risks in agriculture: Simultaneous adoption of diversification and precautionary savings. International Journal of Disaster Risk Reduction, 12, 268-277.

Velandia, M., Rejesus, R. M., Knight, T. O., \& Sherrick, B. J. (2009). Factors affecting farmers' utilization of agricultural risk management tools: the case of crop insurance, forward contracting, and spreading sales. Journal of agricultural and applied economics, 41(1), 107-123.

Wang, J. X., \& Roush, M. L. (2000). What every engineer should know about risk engineering and management. CRC Press.

Wilkinson, E., \& Brenes, A. (2014). Risk-informed decision-making: an agenda for improving risk assessments under HFA2. Produced for the climate and development knowledge 

simultaneous adoption of risk coping tools. Natural Hazards, 84(2), 959-974.

910 Table 1 study area sampling framework

\begin{tabular}{|c|c|c|c|}
\hline $\begin{array}{l}\text { Categorized wheat crop } \\
\text { production zones }\end{array}$ & $\begin{array}{l}\text { Range of wheat crop } \\
\text { production }\end{array}$ & $\begin{array}{l}\text { Sample of wheat crop study } \\
\text { districts }\end{array}$ & $\begin{array}{l}\text { Respondents wheat } \\
\text { farmers in numbers }\end{array}$ \\
\hline \multirow{2}{*}{$\begin{array}{l}\text { Low wheat crop } \\
\text { production zone }\end{array}$} & \multirow{2}{*}{$\begin{array}{l}\text { Wheat production below } \\
600,000 \text { tonnes }\end{array}$} & Dera Ghazi Khan & 80 \\
\hline & & Layyah & 80 \\
\hline \multirow{2}{*}{$\begin{array}{l}\text { Medium wheat crop } \\
\text { production zone }\end{array}$} & \multirow{2}{*}{$\begin{array}{l}\text { Wheat production in range of } \\
600,000 \text { to } 900,000 \text { tonnes }\end{array}$} & Muzaffargarh & 80 \\
\hline & & Vehari & 80 \\
\hline \multirow{2}{*}{$\begin{array}{l}\text { High wheat crop } \\
\text { production zone }\end{array}$} & \multirow{2}{*}{$\begin{array}{l}\text { Wheat production above } \\
900,000 \text { tonnes }\end{array}$} & Rahim Yar Khan & 80 \\
\hline & & Bahawalnagar & 80 \\
\hline
\end{tabular}

911

912

913

Table 2 Study variables descriptive statistics

\begin{tabular}{|c|c|c|c|c|}
\hline Study variables & \multicolumn{2}{|c|}{ Description of variables } & Mean value & $\begin{array}{l}\text { Standard } \\
\text { deviation }\end{array}$ \\
\hline \multicolumn{5}{|l|}{ Dependent variables } \\
\hline Agricultural credit & \multicolumn{2}{|c|}{$\begin{array}{l}\text { Agriculture credit access } 1 \text { otherwise } \\
0\end{array}$} & 0.53 & 0.49 \\
\hline Diversification & \multicolumn{2}{|c|}{ Adopted diversification 1 otherwise 0} & 0.47 & 0.46 \\
\hline \multicolumn{5}{|l|}{ Independent variables } \\
\hline \multicolumn{5}{|c|}{ Socioeconomic and farm characteristics } \\
\hline Schooling status & \multicolumn{2}{|c|}{ Respondents schooling in years } & 3.97 & 5.76 \\
\hline Respondent age & \multicolumn{2}{|c|}{ Respondent age in years } & 36.83 & 12.98 \\
\hline Family monthly income & \multicolumn{2}{|c|}{ Family total monthly income in PKRs } & $29,549.879$ & $18,876.265$ \\
\hline Experience of farming & \multicolumn{2}{|c|}{$\begin{array}{l}\text { Farmer agriculture farming } \\
\text { experience in years }\end{array}$} & 17.871 & 13.546 \\
\hline Size of farm & \multicolumn{2}{|c|}{ Farm land total area in (acres) } & 7.428 & 2.981 \\
\hline Size of family & \multicolumn{2}{|c|}{ Family members in numbers } & 6.324 & 2.872 \\
\hline Ownership of farmland & \multicolumn{2}{|c|}{ Respondent owner 1 otherwise 0} & 0.438 & 0.491 \\
\hline \multicolumn{5}{|l|}{ Perception of risk } \\
\hline Heavy rain & \multicolumn{2}{|c|}{ High risk of heavy rain 1 otherwise 0} & 0.71 & 0.48 \\
\hline Flood & \multicolumn{2}{|c|}{ High risk of flood 1 otherwise 0} & 0.74 & 0.42 \\
\hline Drought & \multicolumn{2}{|c|}{ High risk of drought 1 otherwise 0} & 0.43 & 0.41 \\
\hline Diseases and pests & \multicolumn{2}{|c|}{$\begin{array}{l}\text { High risk of pest diseases } 1 \text { otherwise } \\
0\end{array}$} & 0.79 & 0.46 \\
\hline Hailstorm & \multicolumn{2}{|c|}{ High risk of hailstorm 1 otherwise 0} & 0.39 & 0.40 \\
\hline Heavy wind & \multicolumn{2}{|c|}{ High risk of heavy wind 1 otherwise 0} & 0.47 & 0.44 \\
\hline \multicolumn{5}{|l|}{ Risk attitude } \\
\hline Risk aversion & \multicolumn{2}{|c|}{$\begin{array}{l}\text { Respondent risk averse nature } 1 \\
\text { otherwise } 0\end{array}$} & 0.77 & 0.45 \\
\hline Number of total observations & 480 & & & \\
\hline \multicolumn{5}{|c|}{ Wheat farmers adopted different combinations of risk management strategies } \\
\hline \multicolumn{2}{|c|}{ Strategies of risk management } & Respondents numbers & \multicolumn{2}{|c|}{ Percentage of respondents } \\
\hline \multicolumn{2}{|l|}{ Agricultural credit usage } & 132 & \multicolumn{2}{|c|}{$27.50 \%$} \\
\hline \multicolumn{2}{|c|}{ Diversification usage } & 109 & \multicolumn{2}{|c|}{$22.70 \%$} \\
\hline \multicolumn{2}{|c|}{ Usage of agricultural credit and diversification } & 97 & \multicolumn{2}{|c|}{$20.21 \%$} \\
\hline \multicolumn{2}{|c|}{ Usage of no risk management strategy } & 142 & & $9 \%$ \\
\hline
\end{tabular}


914

915

916

917

918

919

Sources; authors own survey collected data 2019,

Table 3 Bivariate and individual probit model estimated parameters

\begin{tabular}{|c|c|c|c|c|}
\hline \multirow{2}{*}{$\begin{array}{l}\text { Study independent } \\
\text { variables }\end{array}$} & \multicolumn{2}{|c|}{ Individual probit } & \multicolumn{2}{|c|}{ Bivariate probit } \\
\hline & Agricultural credit & Diversification & Agricultural credit & Diversification \\
\hline \multicolumn{5}{|c|}{ Socioeconomic and farm characteristics } \\
\hline Schooling status & $0.0491 * * *(0.0176)$ & $0.0314 * * *(0.0183)$ & $0.0486 * * *(0.0168)$ & $0.0311^{* * *}(0.0179)$ \\
\hline Respondent age & $-0.0287 * *(0.0129)$ & $0.0283 * *(0.0114)$ & $-0.0279 * *(0.0126)$ & $0.0281 * *(0.0112)$ \\
\hline $\begin{array}{l}\text { Family monthly } \\
\text { income }\end{array}$ & $\begin{array}{l}-0.00004 * * * \\
(0.0000)\end{array}$ & $0.00005^{* * *}(0.0000)$ & $\begin{array}{l}-0.00004 * * * \\
(0.0000)\end{array}$ & $0.00005^{* * *}(0.0000)$ \\
\hline $\begin{array}{l}\text { Experience of } \\
\text { farming }\end{array}$ & $-0.0786(0.0691)$ & $-0.1179 *(0.0594)$ & $-0.0781(0.0587)$ & $-0.1293 *(0.0598)$ \\
\hline Size of farm & $0.0579 * * *(0.0189)$ & $-0.0248 *(0.0109)$ & $0.0587 * * *(0.0174)$ & $-0.0239 *(0.0113)$ \\
\hline Size of family & $-0.0138(0.0248)$ & $0.0147(0.0231)$ & $-0.0129(0.0243)$ & $0.0138(0.0227)$ \\
\hline $\begin{array}{l}\text { Ownership of } \\
\text { farmland }\end{array}$ & $-0.6891 * * *(0.1761)$ & $0.7984 * * *(0.1798)$ & $-0.6799 * * *(0.1741)$ & $0.7821 * * *(0.1752)$ \\
\hline \multicolumn{5}{|l|}{ Perception of risk } \\
\hline Heavy rain & $0.4483(0.1798)$ & $0.1289(0.1765)$ & $0.4329(0.1716)$ & $0.1243(0.1741)$ \\
\hline Flood & $-0.6147(0.1987)$ & $-0.2378(0.1799)$ & $-0.6098(0.1924)$ & $-0.2289(0.1765)$ \\
\hline Drought & $0.0236(0.2076)$ & $0.1897(0.1875)$ & $0.0218(0.1987)$ & $0.1861(0.1811)$ \\
\hline Diseases and pests & $0.5798(0.1869)$ & $0.1986(0.1821)$ & $0.5776(0.1834)$ & $0.1954(0.1799)$ \\
\hline Hailstorm & $-0.1797(0.2281)$ & $-0.0139(0.2457)$ & $-0.1785(0.2232)$ & $-0.0134(0.2434)$ \\
\hline Heavy wind & $-0.0597(0.3394)$ & $-0.1187(0.2921)$ & $-0.0582(0.3411)$ & $-0.1178(0.2947)$ \\
\hline \multicolumn{5}{|l|}{ Risk attitude } \\
\hline Risk aversion & $1.0798(0.2289)$ & $0.8789(0.2186)$ & $1.0654(0.2276)$ & $0.8783(0.2197)$ \\
\hline $\begin{array}{l}\text { Value of log } \\
\text { likelihood }\end{array}$ & -189.7865 & -181.9132 & \multicolumn{2}{|c|}{-378.4317} \\
\hline Wald $\chi^{2}$ & \multicolumn{4}{|l|}{$154.98 * * *$} \\
\hline $\begin{array}{l}\text { Ratio of log } \\
\text { likelihood test }{ }_{\mathrm{pkj}}\end{array}$ & \multicolumn{4}{|l|}{$3.8971 * *$} \\
\hline $\begin{array}{l}\text { Ratio of log } \\
\text { likelihood test } \chi^{2}\end{array}$ & $78.56^{* * *}$ & $97.43 * * *$ & & \\
\hline Pseudo- $\mathrm{R}^{2}$ & 0.1867 & 0.2178 & & \\
\hline $\begin{array}{l}\text { Coefficient } \\
\text { correlation }\end{array}$ & \multicolumn{4}{|l|}{$0.389 * * *$} \\
\hline $\begin{array}{l}\text { Total number of } \\
\text { observation }\end{array}$ & \multicolumn{4}{|l|}{480} \\
\hline
\end{tabular}

$* * *$ indicate at $1 \%$ level of significance, $* *$ at $5 \%$ level of significance, *at $10 \%$ level of significance

921 Values in parenthesis reports the standard error 
Table 4 Estimation of Multinomial probit model

\begin{tabular}{|l|l|l|l|}
\hline $\begin{array}{l}\text { Study independent } \\
\text { variables }\end{array}$ & Agricultural credit & Diversification & $\begin{array}{l}\text { Both agricultural credit } \\
\text { and diversification }\end{array}$ \\
\hline Socioeconomic and farm characteristics & $0.0678^{* *}(0.0257)$ & $0.0483(0.0294)$ \\
\hline Schooling status & $0.0593^{* *}(0.0234)$ & $0.0399^{* * *}(0.0173)$ & $-0.0047(0.0198)$ \\
\hline Respondent age & $-0.0269(0.0279)$ & $0.00003^{* * *}(0.0000)$ & $-0.00005^{* * *}(0.0000)$ \\
\hline Family monthly income & $-0.00004^{* * *}(0.00000)$ & $0.0287^{* *}(0.0146)$ & $0.0291(0.0189)$ \\
\hline Experience of farming & $-0.0194(0.0243)$ & $0.2879^{* * *}(0.1179)$ & $0.0298^{* *}(0.0157)$ \\
\hline Size of farm & $0.0149(0.1083)$ & $0.0142(0.0357)$ & $-0.0164(0.0398)$ \\
\hline Size of family & $0.0126(0.0398)$ & $0.7894^{* * *}(0.2687)$ & $1.4786^{* * *}(0.2961)$ \\
\hline Ownership of farmland & $0.5987^{* *}(0,3427)$ & $0.2987(0.2978)$ & $0.1098(0.2976)$ \\
\hline Perception of risk & $-1.4698(0.4379)$ & $-0.2987(2896)$ & $0.4751(0.3781)$ \\
\hline Heavy rain & $0.6789(3954)$ & $0.1793(0.4854)$ & $-0.0721(0.4973)$ \\
\hline Flood & $-0.0796(0.6951)$ & $-0.5879(0.2963)$ & $0.6895(0.3086)$ \\
\hline Drought & $0.2981(0.2811)$ & $-0.1794(0.4681)$ & $-0.2847(0.46825)$ \\
\hline Diseases and pests & $-0.3476(0.5876)$ & $-0.3987(0.5389)$ \\
\hline Hailstorm & $-0.6693(0.7683)$ & $0.1794(0.5431)$ \\
\hline Heavy wind & $0.8976(0.4087)$ & $2.5983(0.4637)$ \\
\hline Risk attitude -298.8976 \\
\hline Risk aversion 480 \\
\hline Value of log likelihood \\
\hline Number of total observations \\
\hline
\end{tabular}

936

937

938

939

940

Figure 1Map of Pakistan provinces and Punjab districts

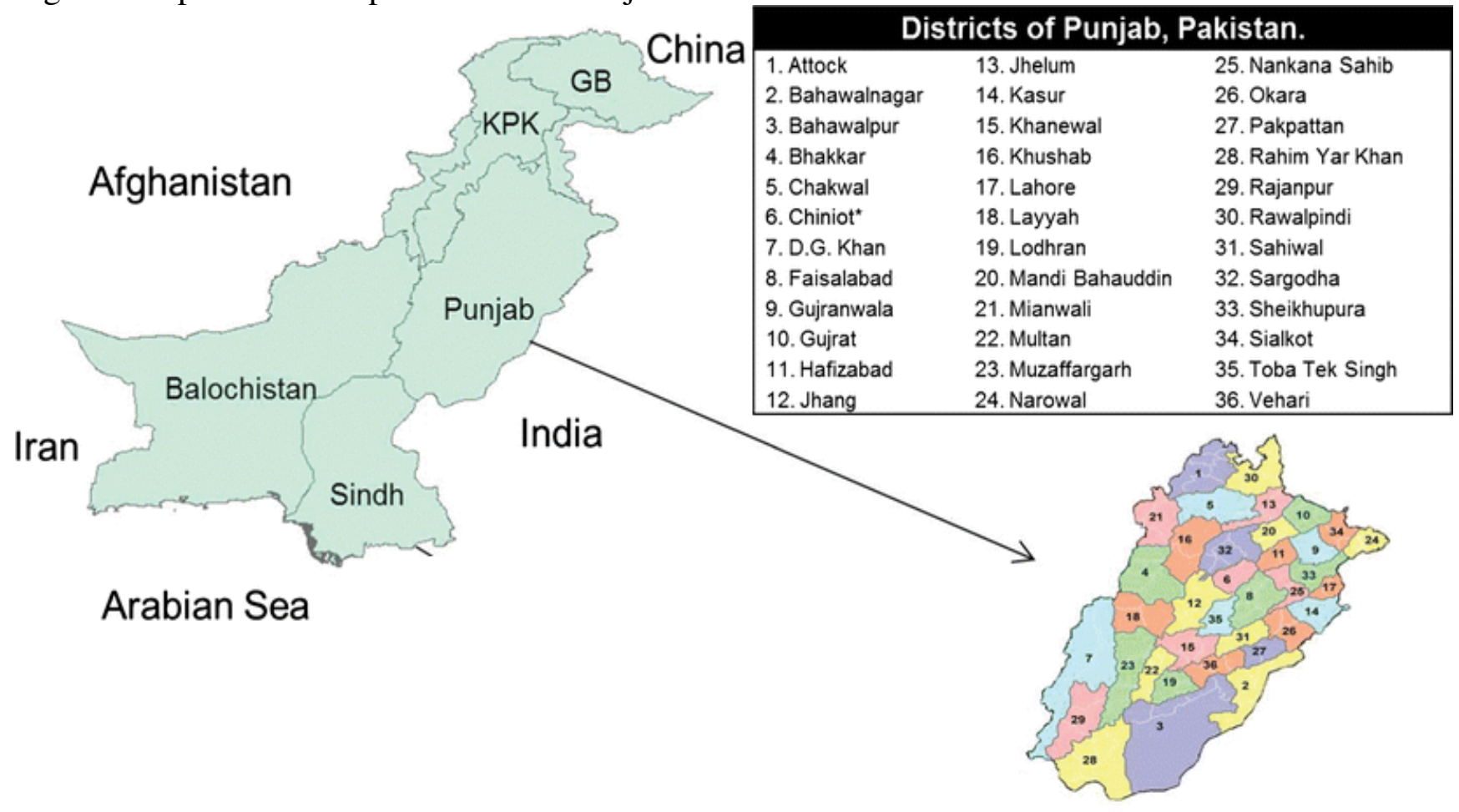

941

942

943

944 
946 Figure 2 Study districts of Punjab province of Pakistan

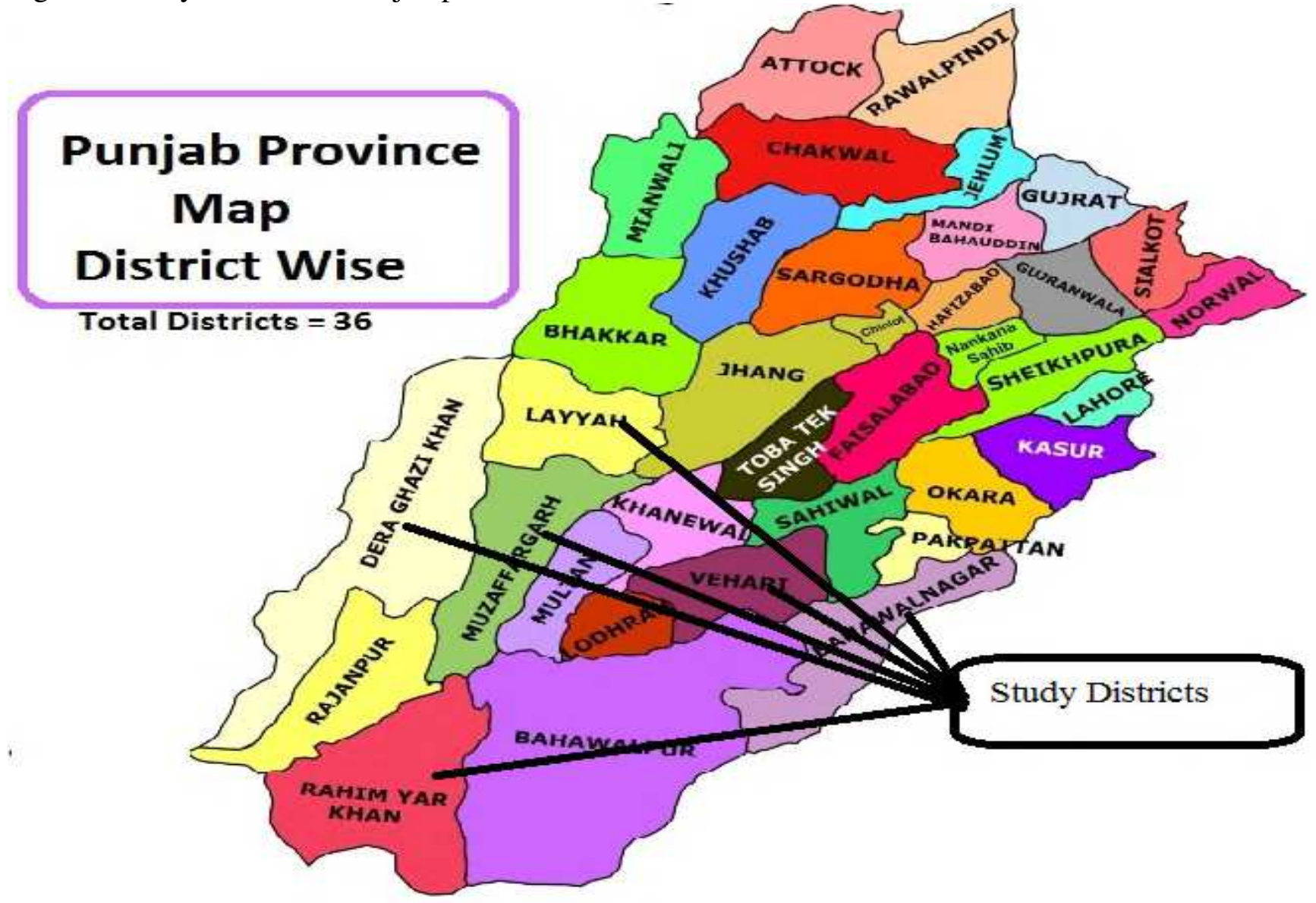

950 Figure 3 Data collection sampling procedure of the study area

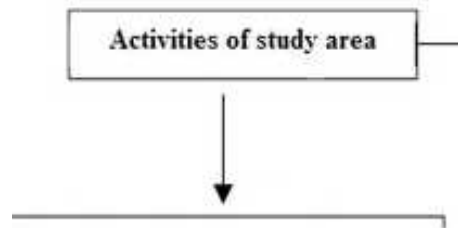

First stage

(June-2019)

Pre-testing questionnier)

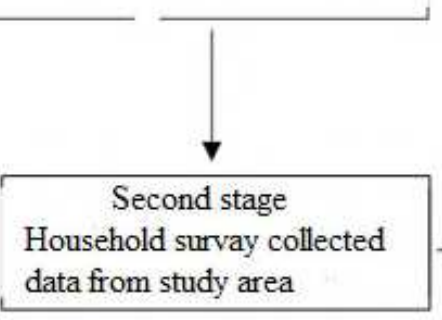

951

952

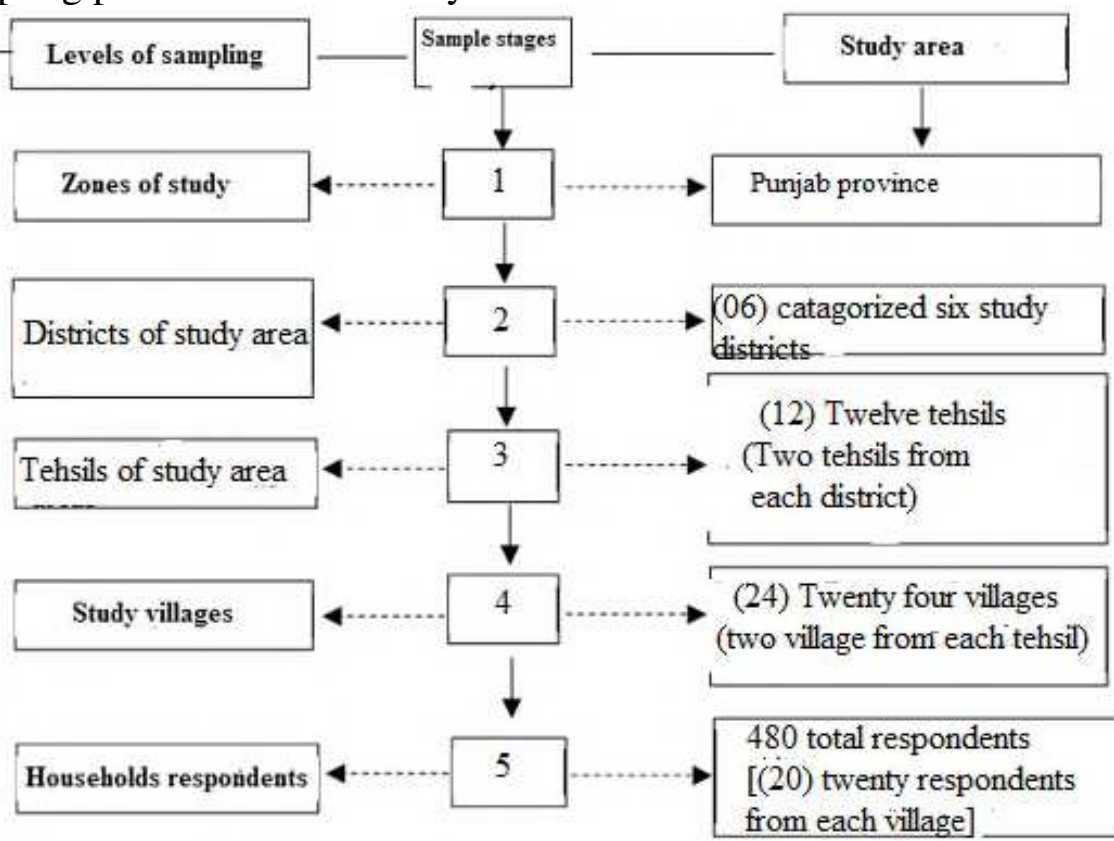

from each village] 
953 Figure 4 Risk Matrix

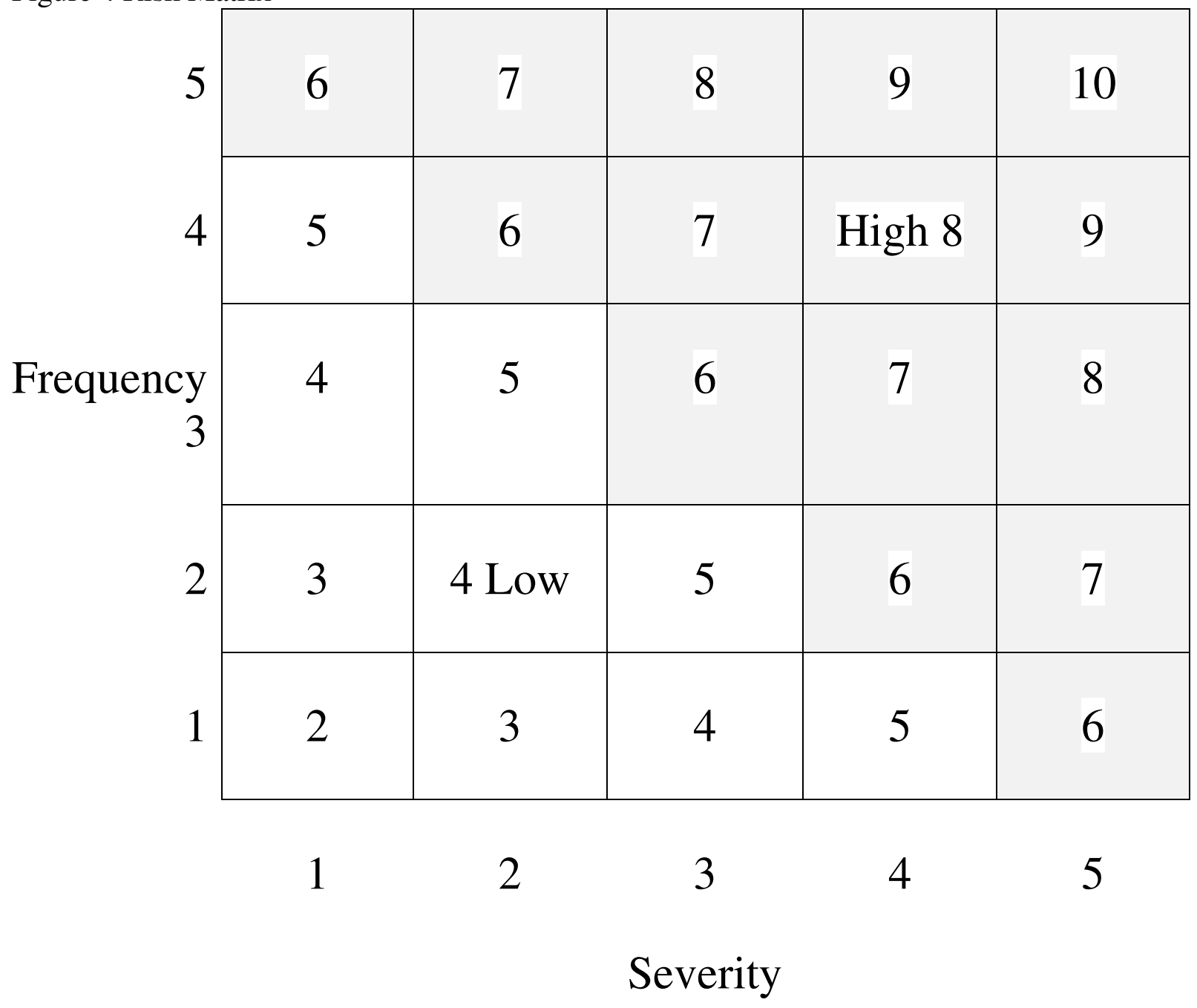

954

955

956

957 